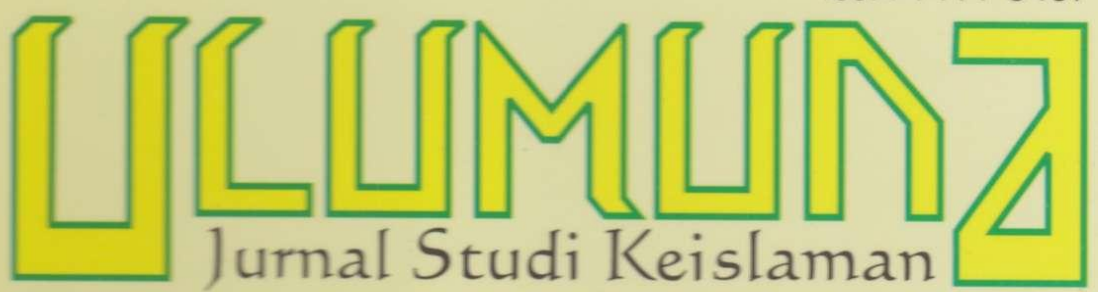

Volume 16 • Nomor 2• Desember 2012

Terakreditası B; SK Dirjen Dikti Kemdikbud Nomor: 56/DIKTI/Kep/2012, Tanggal 24 Juli 2012

REORIENTASI KAJIAN TEOLOGI ISLAM: IKHTIAR KONTRIBUTIF ATASI PROBLEM KEKINIAN Muhammad Rusli

PERGOLAKAN TEOLOGI SYIAH-SUNNI: MEMBEDAH POTENSI INTEGRASI DAN DISINTEGRASI

Slamet Mulyono MEnimbang KontorVERSI PEMAKNAAN KONSEP AHL AL-KITĀB DALAM AL-QUR'AN Zulyadain ECOTHEOLOGY:

TEOLOGI KONSTRUKTIF ATASI KRISIS LINGKUNGAN Abdul Quddus AKU DALAM TUHAN: IMPLIKASI TEOLOGI PROSES PADA ERA KONTEMPORER Suhermanto la'far PERgulatan TEOLOGI SALAFI DALAM MAINSTREAM KEBERAGAMAAN MASYARAKAT SASAK Faizah STUDI KOMPARATIF KONSEP KETUHANAN ISLAM DAN AGAMA ADAM PADA KOMUNITAS SAMIN Mohammad Rosyid KEGALAUAN IDENTITAS:

Dilema Hubungan Komunitas Muslim dan Hindu di BalI Siti Raudhatul Jannah 



\section{DAFTAR ISI}

\section{Pedoman Transliterasi}

\section{3-244 • Muhammad Rusli,}

"Reorientasi Kajian Teologi Islam:

Ikhtiar Kontributif Atasi Problem Kekinian"

245-278 • Slamet Mulyono,

"Pergolakan Teologi Syiah-Sunni:

Membedah Potensi Integrasi dan Disintegrasi"

279-310 • Zulyadain,

"Menimbang Kontorversi Pemaknaan

Konsep Ahl Al-Kitāb Dalam Al-Qur'an"

311-346 • Abdul Quddus,

"Ecotheology:

Teologi Konstruktif Atasi Krisis Lingkungan"

347-374 • Suhermanto Ja'far,

"Aku dalam Tuhan:

Implikasi Teologi Proses pada Era Kontemporer”

375-402 • Faizah,

"Pergulatan Teologi Salafi

dalam Mainstream Keberagamaan Masyarakat Sasak"

403-442 • Mohammad Rosyid,

"Studi Komparatif Konsep Ketuhanan Islam

dan Agama Adam pada Komunitas Samin"

443-464 • Siti Raudhatul Jannah,

"Kegalauan Identitas: Dilema Hubungan

Komunitas Muslim dan Hindu di Bali”

\section{INDEKS}

APENDIKS 


\section{PEDOMAN TRANSLITERASI}

\begin{tabular}{|c|c|c|c|c|c|c|}
\hline 1 & $=$ & $\mathbf{a}$ & & $\dot{\varepsilon}$ & $=$ & $\mathrm{g}$ \\
\hline ب & $=$ & $\mathbf{b}$ & & ف & $=$ & f \\
\hline$ت$ & $=$ & $\mathbf{t}$ & & ق & $=$ & $q$ \\
\hline$\dot{H}$ & $=$ & th & & ك & $=$ & $\mathbf{k}$ \\
\hline ج & $=$ & $\mathfrak{j}$ & & J & $=$ & 1 \\
\hline$\tau$ & $=$ & ha & & s & $=$ & $\mathrm{m}$ \\
\hline$\dot{\tau}$ & $=$ & $\mathbf{k h}$ & & ن & $=$ & $\mathbf{n}$ \\
\hline د & $=$ & d & & و & $=$ & $\mathbf{w}$ \\
\hline ذ & $=$ & dh & & ○ & $=$ & $\mathbf{h}$ \\
\hline Ј & $=$ & $\mathbf{r}$ & & $\varepsilon$ & $=$ & , \\
\hline j & $=$ & $\mathbf{z}$ & & ي & $=$ & $\mathrm{y}$ \\
\hline س س س & $=$ & $\mathbf{s}$ & & & & \\
\hline 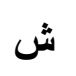 & $=$ & sh & \multicolumn{4}{|c|}{ Untuk Madd dan Diftong } \\
\hline ص & $=$ & ș & i & $=$ & \multicolumn{2}{|c|}{$\bar{a}$ (a panjang) } \\
\hline ض & $=$ & d & إي & $=$ & \multicolumn{2}{|c|}{$\overline{1}$ (i panjang) } \\
\hline b & $=$ & $t$ & 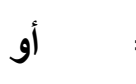 & $=$ & \multicolumn{2}{|c|}{$\bar{u}$ (u panjang) } \\
\hline ظ & $=$ & $\mathrm{z}$ & 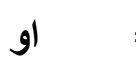 & $=$ & \multicolumn{2}{|c|}{ aw } \\
\hline$\varepsilon$ & $=$ & ‘ & 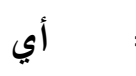 & $=$ & \multicolumn{2}{|l|}{ ay } \\
\hline
\end{tabular}

Contoh penulisan dengan transliterasi:

اعوذ بالله من الشيطان الرجيم (a'üdhu bi al-Lāh min al-shaytān al-rajīm);

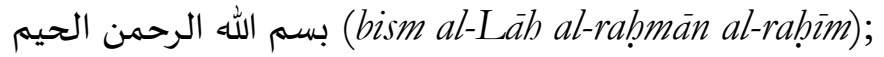

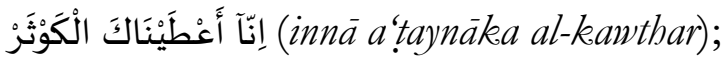

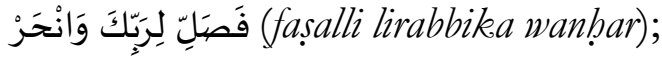

صباح الخير (sabāh al-khayr). 


\title{
KEGALAUAN IDENTITAS: \\ DILEMA HUBUNGAN \\ MUSLIMIN DAN HINDU DI BALI
}

\author{
Siti Raudhatul Jannah \\ (Sekolah Tinggi Agama Islam Negeri [STAIN] Jember \\ Email: jannahnusa@yahoo.com)
}

Abstract: The relationship between Hindu and Muslim communities in Bali has been recorded in the long trajectory of history of both communities. As a buman relationship, the relationship sometimes becomes strength, but at the other hand, as the adherents of different religions, it becomes challenge to them. The challenge is how the Muslim community in Bali can respect and honor Hindu religious traditions, and how the Hindu community can do the same to the Muslim community. The article aims to elaborate further about it. The author presents three cases as examples of how Muslims practice their religion in Bali context. Tolerance is the key word how to mingle in the social, moral principles, religious law and social ethics.

Abstrak: Hubungan antara komunitas Hindu dan Muslim di Bali telah terekam dalam lintasan panjang sejarah dua komunitas itu. Sebagai sebuah hubungan antar manusia, ia kadang-kadang menjadi suatu kekuatan bagi keduanya, tetapi sisi lain, sebagai pengikut agama yang berbeda, ia menjadi suatu tantangan. Tantangan itu adalah bagaimana komunitas Muslim di Bali bisa menghormati tradisi keagamaan Hindu dan bagaimana pula komunitas Hindu menghormati komunitas Muslim. Artikel bertujuan untuk mengelaborasi lebih jauh tentang hal tersebut. Penulis memaparkan tiga contoh kasus tentang bagaimana Muslim menjalankan agama mereka dalam konteks kehidupan di Bali. Toleransi adalah kata kunci bagaimana membaur dalam kehidupan sosial, prinsip moral, bukum agama, dan etika sosial.

Keywords: identitas, tradisi, agama, komunitas muslim, komunitas Hindu, Bali, toleransi, harmoni, etika sosial. 
DITINJAU dari segala aspek, masyarakat Indonesia merupakan masyarakat majemuk (plural). Fenomena ini merupakan realitas yang takterbantahkan bahwa bangsa Indonesia adalah bangsa yang memiliki keanekaragaman suku, ras, agama, dan golongan yang berbeda-beda tetapi tetap satu sebagaimana terdapat dalam semboyan Bhineka Tunggal Ika. Terminologi ini memberikan pemaknaan akan realitas sosial yang terjadi terhadap masyarakat bangsa ini, di satu sisi ada kesadaran akan perbedaan dan di sisi lain perlunya persatuan dan kesatuan. Meski demikian, istilah ini tidak hanya menunjukkan adanya suatu tujuan untuk mencapai suatu tatanan masyarakat yang menyatu, tetapi juga menyembunyikan sikap politik yang sangat tegas untuk menegakkan kesatuan dan persatuan secara total tanpa dapat digugat. ${ }^{1}$

Dari segi etnis misalnya, ada suku Melayu dan suku Melanesia yang selanjutnya membentuk ratusan suku besar dan ribuan suku-suku derivative besar dan kecil. Dari segi sejarah politik lokal, terdapat puluhan bahkan ratusan sistem kerajaan kesukuan lama yang berpengaruh terhadap sistem stratifikasi sosial dan adat istiadat. Dari segi bahasa, terdapat ratusan bahasa yang digunakan di seluruh Nusantara. Dari segi agama, terdapat sejumlah agama besar dunia dan sejumlah sistem kepercayaan lokal yang tersebar di seluruh Nusantara dengan networking-nya masing-masing, baik di dalam maupun di luar negeri. ${ }^{2}$ Dan secara formal, Indonesia terdapat banyak agama yang diakui oleh negara yakni: Islam, Kristen, Katolik, Hindu, Budha, dan Kong $\mathrm{Hu} \mathrm{Cu}$ (Kon Fu Tsio).

Beragama adalah hak yang paling hakiki bagi setiap orang oleh karena memeluk agama merupakan pengejawantahan dari keyakinan akan adanya Tuhan sebagai pencipta alam semesta, sebagai sangkan paraning dumadi. Negara sebagai wadah dan memiliki kekuasaan untuk mengatur wilayah beserta isinya

\footnotetext{
${ }^{1}$ Irwan Abdullah, Konsturksi dan Reproduksi Kebudayaan (Yogyakarta: Pustaka pelajar, 2009), 63.

${ }^{2}$ M. Atho Mudzhar, "Pengembangan Masyarakat Multikultural Indonesia dan Tantangan ke Depan: Tinjauan dari Aspek Keagamaan", dalam M. Ridwan Lubis (ed.), Meretas Wawasan dan Praksis Kerukunan Umat Beragama di Indonesia Jakarta: Badan Litbang Agama dan Diklat Keagamaan Puslitbang Departemen Agama, 2005), 1-2.
} 
berkewajiban untuk memberikan perlindungan dan memfasilitasi setiap proses dan aktifitas keberagamaan. Indonesia sebagai negara yang religius memberikan tempat yang sangat terhormat akan keberagamaan warga negaranya, bahkan memberikan pengakuan akan adanya agama-agama yang hidup dan berkembang di Indonesia.

Namun demikian, fakta juga adanya, keanekaragaman (pluralitas) agama tersebut ternyata sangat rentan melahirkan konflik sosial yang berujung pada tindak kekerasan dan pengrusakan. Sedikit saja ada gesekan, maka dengan mudah timbul kerusuhan massal dan tindak kekerasan kolektif (anarkisme), yang mengakibatkan rakyat yang tidak berdosa harus menderita. Kasus kerusuhan Tasikmalaya, Situbondo (1997); Medan, Jakarta, Solo, Ketapang, dan Kupang (1998); Bali (1999), Ambon, Maluku Utara (1999/2000; 2003/2004), Mataram (2000), Kalimantan (2004), Jakarta (2005), dan Poso (2003-2006) merupakan contoh aktual yang masih segar dalam ingatan. Hal ini sekaligus mengindikasikan bahwa kekerasan sosial begitu fenomenal melanda bangsa Indonesia.

Potensi konflik antarumat beragama sangatlah besar, sebesar pemilahan-pemilahan umat manusia ke dalam batas-batas objektif dan subjektif peradaban. Unsur-unsur pembatas objektif adalah bahasa, sejarah, agama, adat-istiadat, dan lembagalembaga. Adapun unsur pembatas subjektifnya adalah identifikasi yang dilakukan oleh masing-masing individu yang terlibat dalam beragama. Karenanya, perbedaan antarpembatas itu adalah nyata dan penting. ${ }^{3}$ Secara tidak sadar, manusia terkelompok ke dalam identitas-identitas yang membedakan antara satu dengan yang lainnya. Dan tentu saja, membutuhkan ekspresi identitas diri dalam berbagai bentuk, meski memerlukan adanya suatu sistem yang dapat menjamin koeksistensi atau bahkan mungkin saling bekerjasama. ${ }^{4}$

Masyarakat majemuk ala Indonesia ini tentu saja memiliki budaya dan aspirasi yang beraneka ragam yang terkadang

${ }^{3}$ Samuel P. Huntington, "Benturan Antar Peradaban, Masa Depan Politik Dunia?” dalam Jurnal Ulumul Qur'an, No. 5, Vol.IV Tahun 1993, 12.

${ }^{4}$ Leo Suryadinata, et.al., Indonesia's Population (Singapore: Institue of Southeast Asian Studies (ISEAS), 2003), 10. 
menimbulkan konflik, karena adanya pemaknaan tunggal atas kebenaran, dominasi, hegemoni terhadap yang lain. Ini sering berimplikasi pada rasa ketidakadilan dan ketidaksetaraan yang membawa sentimen kelompok yang semakin mengkristal. Apalagi, perbedaan yang terjadi dibungkus dengan label agama, maka yang terjadi adalah ketegangan sosial yang semakin tersedimentasi yang muaranya dapat menimbulkan konflik yang tak berkesudahan.

Karenanya, konflik di kalangan masyarakat beragama, tidak hanya dapat dilihat dari konflik agama semata-mata, melainkan juga faktor pemicunya, seperti motif politik, ekonomi, sosial, dan kekuasaan. Hal ini menegaskan bahwa agama tidak mungkin terbebas dari persoalan-persoalan publik dalam sebuah negara yang berhubungan dengan sistem politik, ekonomi, budaya, dan sistem sosial yang berkembang. Agama akan menjadi persoalan ketika dihadapkan pada persoalan sekularisasi yang inheren dengan ruang publik dan privat. ${ }^{5}$ Aktualisasi ini didasarkan atas kesadaran kolektif bahwa kehidupan itu dinamis sehingga tantangan dan hambatan yang terjadi pun bersifat dinamis sesuai dengan semangat zaman.

Konflik di berbagai tempat menurut Irwan Abdullah sesungguhnya merupakan bentuk resistensi masyarakat terhadap berbagai tindakan kebijakan pusat. ${ }^{6}$ Karena itu, keragaman etnis, bahasa, budaya maupun agama setidaknya dapat dilihat dari tiga proses penting. Pertama, pengingkaran atas status agama yang beragam yang terjadi dalam berbagai bentuk yang kemudian melahirkan berbagai persoalan yang menjauhkan Indonesia dari sifat Bhineka Tunggal Ika. Kedua, politik uniformitas yang bertolak belakang dari keragaman agama karena penyeragaman terjadi pada skala yang sangat luas dan pada tingkatan yang bervariasi. Ketiga, kegagalan pemerintah dalam menjaga keseimbangan antarpenganut umat beragama dalam masyarakat. Ketiga faktor tersebut menegaskan bahwa konflik-konflik agama yang terjadi di Indonesia selama ini bukan semata-mata persoalan perbedaan budaya, etnis maupun agama, tetapi sudah

5Jose Cassanova, Agama di Ruang Publik: Kebidupan Dunia di Alam Modern (Malang: Resist Book, 2001), 47.

${ }^{6}$ Abdullah, Konsturksi dan Reproduksi, 71. 
lebih mengakar pada kesalahan dari berbagai pihak dalam mengelola perbedaan dan konflik itu sendiri. ${ }^{7}$

Berangkat dari pemaparan di atas, tulisan ini bertujuan untuk menjelaskan bagaimana masyarakat Bali yang beragama Islam dan Hindu saling merespon terhadap berbagai bentuk interaksi sosial yang melibatkan nilai-nilai agama yang terkadang saling bertentangan menurut penganutnya.

\section{Konflik dan Pluralisme Agama}

Terbentuknya Forum Kerukunan Umat Beragama (FKUB) dapat dijadikan sebagai bukti bahwa sentimen agama dapat dengan mudah melahirkan konflik bahkan dibangkitkan untuk melakukan perlawanan dengan tujuan-tujuan tertentu. Konflik yang bersumber pada agama ini terjadi pada berbagai tingkatan, baik dalam agama itu sendiri maupun antara satu agama dengan agama yang lain. Meski demikian, dinamika sosial yang diperlihatkan melalui konflik agama ini tidaklah berdiri sendiri, melainkan terkait dengan berbagai parameter lainnya. ${ }^{8}$

Pluralisme merupakan tantangan bagi agama-agama. Dari sinilah arti penting pencarian titik temu (konvergensi) agamaagama. Ada beberapa pertimbangan sebagai kerangka acuan akan arti pentingnya pencarian konvergensi agama-agama. Pertama, secara praktis pluralisme agama belum sepenuhnya dipahami umat beragama, sehingga yang tampil ke permukaan justru sikap eksklusifisme beragama, yang merasa ajaran yang paling benar hanyalah agama yang dipeluknya. Agama-agama lain dituduh sesat, maka wajib dikikis atau pemeluknya ditobatkan, karena baik agama maupun pemeluknya terkutuk dalam pandangan Tuhan. Di sinilah akar konflik dimulai, meski pluralimse agama memang belum sepenuhnya menjamin kerukunan hidup beragama. Kedua, di tengah-tengah pluralisme agama ini, hanyalah pemeluk agama tertentu (yang bersikap eksklusif) justru masih cenderung memonopoli kebenaran agama (claim of truth) dan lahan keselamatan (claim of salvation). Pahadal secara sosiologis, claim of truth dan claim of salvation itu, selain 
membuat berbagai konflik sosial politik, juga membawa berbagai macam perang antaragama. ${ }^{9}$

Kenyataan juga memperlihatkan bahwa agama merupakan suatu sistem yang integral. Koentjaraningrat dengan mengutip pendapat Emile Durkheim dalam karyanya yang terkenal Les Formes Elementaires de la vie Religieuse, ada empat unsur pokok dalam agama, yaitu emosi keagamaan, sistem kepercayaan, sistem upacara, dan komunitas keagamaan. ${ }^{10}$ Emosi keagamaan menyebabkan manusia menjadi religius. Sistem kepercayaan mengandung keyakinan serta bayangan-bayangan manusia tentang sifat-sifat Tuhan serta tentang wujud dari alam gaib. Sistem upacara religius yang bertujuan mencari hubungan manusia dengan Tuhan, dewa-dewa atau mahluk-mahluk halus yang mendiami alam gaib. Dan, kelompok-kelompok religius atau kesatuan-kesatuan sosial yang menganut sistem kepercayaan dan melakukan sistem upacara-upacara religius.

Dalam hubungan antar komunitas dan emosi keagamaan, akan terbentuk ikatan primer dan solidaritas kelompok, mengingat emosi keagamaan merupakan juga dasar ikatan primer dalam komunitas masyarakat dan sumber dari sentimen kemasyarakatan, di mana kesadaran tentang hubungan itu menjadi paling kuat dan paling mudah disinggung dan dilukai. Sehingga, umat beragama gampang disulut bagi timbulnya konflik mengatasnamakan agama. ${ }^{11}$

Kerukunan hidup beragama merupakan ciri dari potensi integrasi yang terdapat dari adanya kehidupan berbagai agama. Mewujudkan kerukunan hidup beragama atau potensi integrasi setidaknya memerhatikan faktor penghambat dan penunjang. Beberapa faktor penghambat kerukunan hidup beragama antara lain: warisan politik imperialis, fanatisme dangkal, sikap sentimen, cara-cara agresif dalam penyebaran agama, pengaburan nilai-nilai ajaran agama antara satu agama dengan

'Sukidi, "Dari Pluraisme Agama Menuju Konvergensi Agama-agama", KOMPAS, 17 Oktober 1998.

${ }^{10}$ Koentjaraningrat, Kebudyaaan, Mentalitet dan Pembangunan (Jakarta: Gramedia, 1978), 136-7.

${ }^{11}$ Masykur, "Pola Komunikasi Antar Umat Beragama: Studi atas Dialog Umat Islam dan Kristen di Kota Cilegon Banten" Article Annual conference on contemporary Islamic studies, Jakarta: tt., 6 . 
yang lain, maupun ketidakmatangan dan ketertutupan penganut agama itu sendiri. Bahkan, karena masih kuatnya kultur patriarkal. Sedangkan, beberapa faktor pendukung dalam upaya kerukunan hidup beragama yaitu adanya nilai gotong-royong, saling menghormati kebebasan menjalankan ibadah sesuai dengan agamanya, kerja sama di kalangan intern maupun antarumat beragama, kematangan, keterbukaan sikap para penganut agama.

\section{Bali dalam Keragaman Agama dan Budaya}

Penganut Hindu yang mayoritas (sekira 93 persen dari total jumlah penduduk Bali), seringkali "melibatkan" atau mengundang umat Islam untuk terlibat dalam kegiatan keagamaan mereka, atau dalam kegiatan kemanusiaan yang seringkali tak dapat dipisahkan dengan peribadatan keagamaan mereka. Hal ini dilakukan sebagai tanda penghormatan Umat Hindu akan keberadaan Muslim di tanah leluhur mereka. Bagaimana umat Islam berpartisipasi dalam kehidupan umat Hindu yang mayoritas ini, namun tetap mempertahankan akidah Islamnya? Temuan penulis yang tinggal puluhan tahun di sana, mencoba menggambarkan dengan gamblang.

Penulis awali dengan pemaparan sejarah masuknya Islam di Bali, menurut beberapa temuan diperkirakan terjadi sekitar abad 14 dan 15. Salah satu buktinya terdapat dalam Kidung Pamacangah yang mengangkat cerita tentang keberadaan sebuah kerajaan di Bali yang berpusat di Gel-gel, Klungkung. Pada saat yang bersamaan jatuhlah Kerajaan Majapahit dan mulai berdirinya Kesultanan Demak, menandai meluasnya ajaran Islam di tanah Jawa termasuk di luar Jawa. ${ }^{12}$

Diceritakan dalam Kidung Pamacangah, utusan Kerajaan Demak datang ke Gel-gel untuk mengislamkan Raja Ida Dalam Waturenggong yang pada saat itu memerintah kerajaan. Usaha tersebut gagal, beberapa utusan Demak kembali ke Jawa. Namun, ada beberapa di antaranya memutuskan untuk tinggal di Gel-gel, oleh kerajaan mereka diberi tanah perdikan untuk ditempati. Hingga saat ini di Gel-gel terdapat satu kampung

${ }^{12}$ Pemda Tk.I Bali, Sejarah Masuknya Agama Islam ke Bali (Proyek Peningkatan Sarana dan Prasarana Kehidupan Beragama, 1997/1998), 5. 
Islam yang dikenal dengan kampung Islam Gel-gel. ${ }^{13}$ Di sisi lain, Bali merupakan benteng terakhir agama Hindu di Nusantara (Indonesia). Keseluruhan tatanan sosial kemasyarakatan diatur sedemikian rupa berdasarkan hukum adat. Konsep Bali sebagai satu-kesatuan adat pertama kali dicetuskan oleh Mpu Kuturan. Hingga kini, Pulau Bali habis terbagi menjadi wilayah-wilayah desa adat (pekraman), kecuali pada kantong-kantong non Hindu seperti di Gel-gel. ${ }^{14}$

Awig-awig, atau aturan/pranata yang dibuat secara musyawarah mufakat, ditahbiskan sebagai sebuah pedoman berperilaku di wilayah masing-masing desa adat. Dengan demikian, awig-awig ini mengikat warga di suatu wilayah termasuk di dalamnya pendatang dari luar, untuk mengikuti apa yang termaktub dalam aturan tersebut. Beberapa aspek penting yang diatur dalam awig-awig tersebut di antaranya aspek hubungan kewilayahan (palemahan), kemasyarakatan (pawongan) dan keagamaan (parbyangan). ${ }^{15}$

Sebagaimana layaknya sebuah aturan, maka awig-awig ini juga memiliki sanksi-sanksi yang secara umum dibagi menjadi tiga bagian. Pertama, sanksi yang diberikan berkaitan dengan harta benda (artha danda), kedua, sanksi yang berkaitan dengan nestapa jiwa atau fisik (jiwa danda), dan ketiga, sanksi yang berkaitan dengan pengembalian keseimbangan alam ghaib (penyangaskara danda). ${ }^{16}$

Karenanya, masyarakat Muslim Bali yang secara otomatis menjadi bagian dari masyarakat Bali, setidaknya harus mengikuti peraturan yang berlaku di kalangan masyarakat yang mayoritas penganut Hindu, meski kadang bertentangan dengan aturan agama Islam. Namun demikian, sesuai berjalannya waktu, umat Islam di Bali, baik yang jauh maupun dekat dengan Gel-gel Kabupaten Klungkung, pusat pertumbuhan Islam di Bali, akhirnya memiliki kearifan-kearifan lokal yang pastinya akan

\section{${ }^{13}$ Ibid., 7.}

${ }^{14}$ Utami Pidada, “Ahimsa, Gaya Hidup Tanpa Kekerasan”, dalam Faisal Zein, Helmy, et.al (ed.), Agama dan Kekerasan, Dari Anarkisme Politik ke Teologi Kekerasan (Jakarta: Elsas, 1999), 11.

15I Gde Parimastha, "Memahami Ddesa Adat, Desa Dinas dan Desa Pekraman (Suatu Tinjauan Historis Kritis)", Makalah, Bali: Universitas Udayana Bali, 2005.

${ }^{16}$ Ibid. 
unik bila dibandingkan dengan Muslim di pulau atau provinsi di luar Bali.

\section{Merajut Persaudaraan}

Munculnya konflik agama di Indonesia dinilai sebagai bentuk beragama secara formal (formalisme agama) dan jatuh pada simbolisme. Artinya, ketika agama dihayati secara formal, maka kesalehan yang muncul dari penghayatan itu adalah sebuah kesalehan individual dan atau kesalehan kolektif yang sempit, dan celakanya diarahkan pada perusakan lingkungan seputar rumah ibadah atau tempat-tempat ibadah lainnya. ${ }^{17}$

Akibat yang muncul kemudian adalah agama justru menjadi terasing dengan persoalan kehidupan manusia. Agama yang seharusnya menjadi pembebas, malah terjebak pada aspek romantisme formal.

\section{Undangan Makan Bersama}

Salah satu aspek yang dialami oleh Muslim yang hidup di Bali adalah undangan makan dari rekan mereka yang beragama Hindu sebagai tuan rumah. Sebagaimana diketahui, masyarakat Hindu sangat menyukai daging babi sebagaimana Muslim menyukai daging sapi. Padahal keharaman daging babi dalam Islam merupakan sesuatu yang qat'i, jelas dan tidak diragukan lagi. Pun demikian dengan pandangan masyarakat Muslim di Bali.

Hal ini memang menjadi persoalan bagi Muslim di Bali, baik secara individu maupun kelompok. Misalnya kala ada undangan pernikahan, kelahiran maupun dalam rangka kunjungan biasa. Kala undangan ini dipenuhi, biasanya tuan rumah menyuguhi aneka makanan dan minuman. Kalau terjadi siang hari, masih lumayan karena bisa beralasan sedang puasa, bagaimana kalau di malam hari?

Menyikapi fakta sosial ini, Muslim di negeri Dewata yang terdiri dari sembilan kabupaten dan satu kotamadya itu, dituntut

${ }^{17}$ Romo Beny Susetyo, "Agama dan Konflik Sosial: Merajut Persaudaraan Sejai", dalam M. Ridwan Lubis (ed.), Meretas Wawasan dan Praksis Kerukunan Umat Beragama di Indonesia (Jakarta: Badan Litbang Agama dan Diklat Keagamaan Puslitbang Departemen Agama, 2005), 69. 
memiliki kecerdasan emosional dan intelektual agar dapat menghindari mengkonsumsi babi tanpa menyinggung si pengundang yang Hindu atau tuan rumah. Umumnya, Muslim yang sudah bertahun-tahun hidup di Bali akan menghindari makanan hasil olahan yang dipastikan telah "terintrusi" dagingminyak-tulang babi. Seperti opor, telur bumbu, sate, kue basah dan minuman yang disajikan dalam gelas. Apa pasal? meskipun ada menu non babi seperti ayam (masyarakat Hindu umumnya mensucikan daging sapi dan tidak mengkonsumsinya), namun minyak dan alat untuk memasaknya dipastikan satu sumber.

Lalu, bagaimana agar pengundang tidak kecewa karena tamunya yang Muslim tidak mengkonsumsi suguhan yang dihaturkan? Muslim yang datang ke undangan tersebut biasanya memilih menu non olahan si tuan rumah dan beralih kepada makanan yang lazim didapat dari toko modern yang di kemasannya biasanya terdapat jaminan halal. Misalnya roti-rotian (biasanya roti sisir atau roti khas Jawa yang diekspor ke Bali), buah-buahan dan minuman kemasan seperti air mineral atau produk minuman bersoda yang umum dijadikan sajian umat Hindu kala mengundang pihak luar.

Menurut penulis, interaksi antara umat beragama Hindu dengan Muslim di Bali telah berlangsung lama, menyebabkan pengetahuan orang Bali tentang cara pandang Islam terhadap persoalan makanan yang haram (khususnya babi) semakin terbuka. Saat ini, Umat Hindu di Bali jarang yang menyuguhi tamu Muslimnya dengan makanan hasil olahan mereka kala punya hajat. Biasanya mereka akan menyediakan makanan jenis lain yang menurut pandangan mereka boleh dimakan, yang dibeli di pusat-pusat perbelanjaan modern yang tersebar di seluruh Bali.

Di sisi berbeda, Muslim di Bali umumnya kukuh melaksanakan ajaran Islam, bahwa Islam mengatur sangat detail tentang masalah makanan. Hingga pada persoalan jenis sembelihan yang diperbolehkan oleh syara'. Allah Swt berfirman:

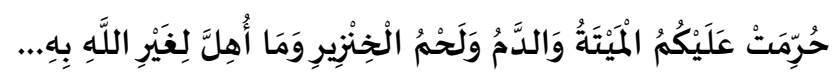

Artinya: "diharamkan bagimu (memakan) bangkai, darah, daging babi, (daging hewan) yang disembelih atas nama selain Allah..." (Qs. al-Mā’idah [5]: 3). 
Tentang hal ini tidak banyak diketahui oleh orang Hindu Bali. Bagi mereka, dengan menyuguhkan makanan non babi (ayam, bebek, sapi dll), maka otomatis "halal" dan orang Islam boleh memakannya. Padahal proses penyembelihan dan pengolahannya tidak berasaskan Islam. Sementara di sisi lain Islam telah mengatur bahwa semua sembelihan haram hukumnya jika tidak disembelih dengan cara yang dibenarkan oleh syara'.

Islam mengatur umatnya dalam masalah makanan (ta'am) yaitu ketentuan boleh dan tidaknya suatu barang atau hidangan disantap oleh manusia, sebagaimana firman Allah Swt:

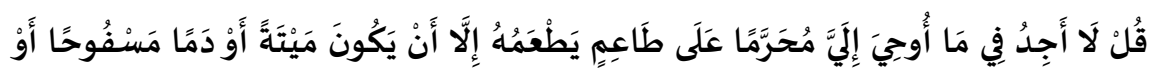

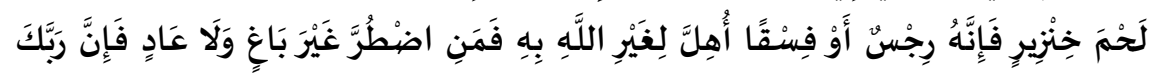

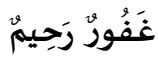

Artinya: "Katakanlab: "Tiadalah aku peroleh dalam wahyu yang diwahyukan kepadaKu, sesuatu yang diharamkan bagi orang yang hendak memakannya, kecuali kalau makanan itu bangkai, atau darah yang mengalir atau daging babi - karena Sesungguhnya semua itu kotor - atau binatang yang disembelib atas nama selain Allah. Barangsiapa yang dalam keadaan terpaksa, sedang Dia tidak menginginkannya dan tidak (pula) melampani batas, Maka Sesunggubnya Tubanmu Maba Pengampun lagi Maha Penyayang". (Qs. alAn‘ām, [6]: 145).

Haramnya beberapa item sebagaimana tersebut dalam ayat tersebut di atas dipertegas lagi oleh Allah, sebagaimana termaktub dalam Qs. al-Mā'idah [5] ayat 3 berikut:

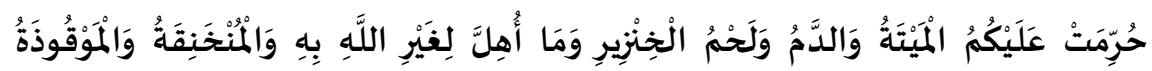

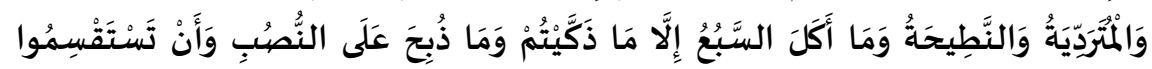

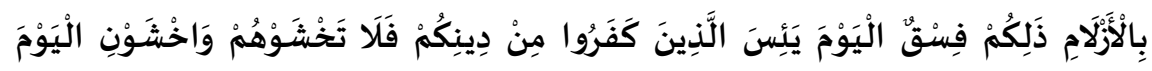

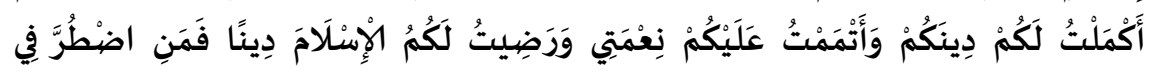

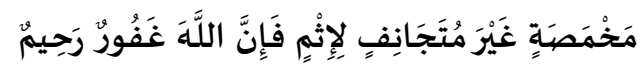

Artinya: "dibaramkan bagimu (memakan) bangkai, darah, daging babi, (daging hewan) yang disembelih atas nama selain Allah, yang tercekik, yang terpukul, yang jatuh, yang ditanduk, dan diterkam binatang buas, kecuali yang sempat kamu menyembelihnya, dan (diharamkan bagimu) yang disembelih untuk berbala. dan (dibaramkan juga) mengundi nasib dengan anak panah, (mengundi nasib dengan anak panah itu) adalah kefasikan. pada hari ini orang-orang kafir telah putus asa untuk. (mengalabkean) agamamu, sebab itu 
janganlah kamu takut kepada mereka dan takutlah kepada-Ku. pada hari ini telah Kusempurnakan untuk kamu agamamu, dan telah Ku-cukupkan kepadamu nikmat-Ku, dan telah Ku-ridhai Islam itu Jadi agama bagimu. Maka barang siapa terpaksa karena kelaparan tanpa sengaja berbuat dosa, Sesunggubnya Allah Maba Pengampun lagi Maha Penyayang."

Artinya bagi orang yang memakannya, tidak dihalalkan makan kecuali jika makanan itu baik dan jiwa dapat terpelihara, sebagaimana firman Allah Swt:

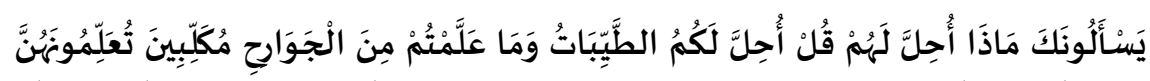

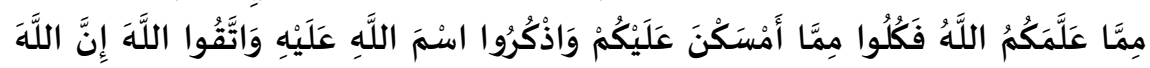

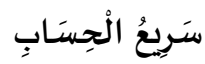

Artinya: "mereka menanyakan kepadamu: "Apakah yang Dihalalkan bagi mereka?". Katakanlah: "Dihalalkan bagimu yang baik-baik dan (buruan yang ditangkap) oleh binatang buas yang telah kamu ajar dengan melatib nya untuk berburu; kamu mengajarnya menurut apa yang telah diajarkan Allah kepadamu. Maka makanlah dari apa yang ditangkapnya untukmu dan sebutlah nama Allah atas binatang buas itu (waktu melepaskannya) dan bertakwalah kepada Allah, Sesungoubnya Allah Amat cepat hisab-Nya". (Qs. al-Mā’idah, [5]: 4)

Yang dimaksudkan baik di sini adalah apa yang dianggap dan dirasakan oleh jiwa baik. Hal ini seperti firman Allah swt:

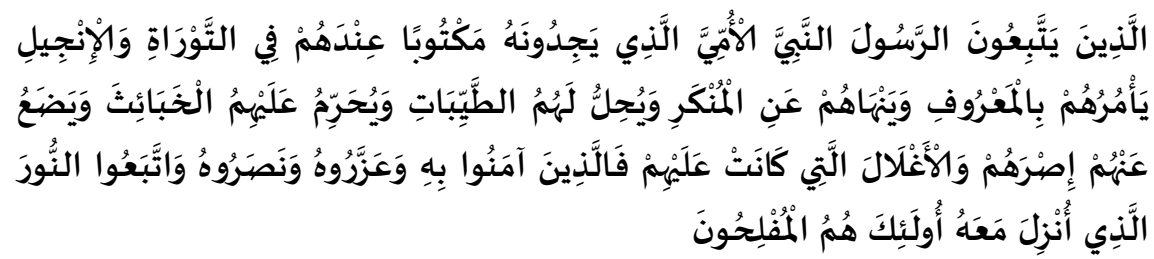

Artinya: "(yaitu) orang-orang yang mengikut rasul, Nabi yang Ummi yang (namanya) mereka dapati tertulis di dalam Taurat dan Injil yang ada di sisi mereka, yang menyuruh mereka mengerjakan yang ma'ruf dan melarang mereka dari mengerjakan yang mungkar dan menghalalkan bagi mereka segala yang baik dan mengharamkan bagi mereka segala yang buruk dan membuang dari mereka beban-beban dan belenggu-belenggu yang ada pada mereka. Maka orang-orang yang beriman kepadanya. memuliakannya, menolongnya dan mengikuti cabaya yang terang yang diturunkan kepadanya (Al Quran), mereka Itulab orang-orang yang beruntung”. (Qs. al-A'rāf, [7]: 157).

Karena aturan Islam inilah, Muslim di Bali senantiasa dihadapkan kepada realita untuk selalu berkecerdasan dalam memilah dan memilih santapan dan hidangan para pengundang 
non Islam-nya tanpa menyinggung perasaan si tuan rumah. Caranya, memakan apa yang paling mungkin tidak dibuat sendiri oleh tuan rumah atau dimasak oleh non Muslim dan mengkonsumsi makanan yang umumnya hanya dibuat orang Jawa dan Lombok -dua pulau yang mengitari Bali. Dengan kiat inilah, Muslim di Bali terus bertahan dengan akidah mereka namun dapat hidup berdampingan dengan nyaman dan aman dengan penganut Hindu di Jawa Dwipa tersebut.

\section{Doa Bersama}

Dalam kehidupan sosial, interaksi yang terjadi juga terkadang menyentuh persoalan-persoalan peribadatan. Salah satunya adalah doa bersama. Lebih khusus di kalangan pemerintahan. Jajaran birokrasi di Bali hampir seluruhnya menganut agama Hindu, pun demikian dengan acara-acara seremonial maka doa yang dibacakan oleh pembaca doa tentu menggunakan mantrammantram (doa) menurut agama Hindu. Di lingkungan individu, memang jarang terjadi. Biasanya masalah ini timbul dari hubungan antar personal yang saling menasehati dan saling memberi doa, padahal mereka berbeda keyakinan.

Mengingat doa bersama adalah persoalan ibadah, umat Islam di Bali umumnya berdoa dengan keyakinan Islam meski yang sedang dibaca oleh protokoler-petugas pembaca doa adalah mantram Hindu. Muslim tidak lari dari forum semisal upacara atau doa bersama, namun sejak detik pertama pembacaan doa biasanya membaca ummul qur'an atau diam membatu sampai acara berdoa selesai.

Pasalnya, doa yang memakai "media" agama lain jelas keharamannya, sebagaimana diatur Majelis Ulama Indonesia (MUI) melalui keputusannya No. 3/MUNAS/VIL/7/2005, menetapkan fatwa tentang pelaksanaan doa bersama berdasarkan dalil-dalil, yakni: Qs. al-Naml [27]: 62, Qs. alMāidah [5]: 73, Qs. Gāfir [40]: 50, Qs. al-Furqān [25]: 68, Qs. alBaqarah [2]: 42 dan Qs. al-Kāfirūn [109]: 1-6. Salah satunya dapat penulis kutip Qs. al-Naml (27) ayat 62 berikut:

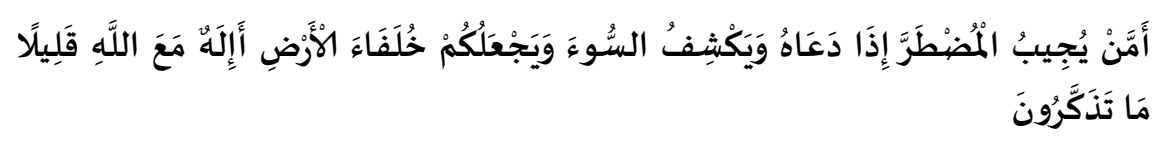


Artinya: "atau siapakah yang memperkenankan (doa) orang yang dalam kesulitan apabila ia berdoa kepada-Nya, dan yang menghilangkan kesusahan dan yang menjadikan kamu (manusia) sebagai khalifah di bumi? Apakah disamping Allah ada Tuhan (yang lain)? Amat sedikitlah kamu mengingati(Nya).”

Penetapan tersebut juga berdasarkan hadith Nabi Muhammad Saw.: "Doa adalah otak (inti) ibadah." (HR. Tirmidzi)

Qaidah fiqh: "Hukum asal dalam masalah ibadah adalab taufiq dan ittiba' (mengikuti petunjuk dan contoh Nabi)."18

Berdasarkan pertimbangan di atas fatwa MUI menegaskan bahwa: (1) Doa bersama yang dilakukan oleh orang Islam dan non muslim tidak dikenal dalam Islam. Oleh karenanya, termasuk bid'ah (2) Doa bersama dalam bentuk setiap pemuka agama berdoa secara bergiliran maka orang Islam haram mengikuti dan mengamini doa yang dipimpin oleh non muslim (3) Doa bersama dalam bentuk muslim dan non muslim berdoa secara serentak hukumnya haram (4) Doa bersama dalam bentuk seorang non Islam memimpin doa, maka orang Islam haram mengikuti dan mengamininya (5) Doa bersama dalam bentuk seorang tokoh Islam memimpin doa hukumnya mubah (6) Doa bersama dalam bentuk setiap orang berdoa agama masingmasing hukumnya mubah.

Dari keputusan/fatwa MUI tersebut di atas, minimal dapat memberi masukan-masukan kepada umat Islam, pun di Bali. Memang diperlukan sosialisasi yang terus-menerus dengan mengedepankan mau'izah yang hasanah agar tidak terjadi ketersinggungan di pihak lain. Persoalannya, sering kali inti agama/ibadah (dalam hal ini masalah doa) selalu dibenturkan dengan doktrin hubungan antarmanusia. Tetapi di sisi lain telah jelas bagaimana Islam mengatur umatnya untuk tidak mencampuradukkan urusan kemanusiaan dengan urusan akidah di tengah-tengah keragaman agama.

\section{Shalat Jum'at pada Hari Raya Nyepi}

Nyepi (hari raya Nyepi) merupakan salah satu hari besar umat Hindu khususnya di Bali, untuk merayakan tahun baru

${ }^{18}$ Beberapa pendapat para ulama (qawl 'ulama') dapat dilihat dalam beberapa kitab rujukan seperti Hasyiyah al-Jamal Fath al-Wabhab, juz V, 226; Hasyiyah al-Jamal, juz II, 119; Mughniy al-Mubtaj, juz I, 233; al-Majmu', juz v, h.72, 66. 
Caka. Pada hari itu, umat Hindu melaksanakan suatu ritual dengan apa yang disebut Catur Brata Penyepian, yaitu amati mekarya (tidak beraktifitas dalam melaksanakan pekerjaan), amati geni (tidak memasak/berpuasa), amati lelungan (tidak bepergian) dan amati lelanguan (tidak menikmati hiburan/menyepi).

Selama pelaksanaan ritual Nyepi, seluruh aktifitas kegiatan dihentikan dalam waktu 24 jam (dari jam 06.00 hingga jam yang sama pada hari berikutnya). Kendaraan tidak boleh keluar (kecuali ambulan), lampu dimatikan, tidak boleh keluar rumah, tidak ada kapal laut yang bersandar untuk masuk ke Bali, tidak ada pesawat yang boleh mendarat di bandara dan tidak boleh ada penerangan (sinar) di malam hari. Pada hari itu Bali ibarat pulau mati yang tidak memiliki aktifitas sama sekali.

Walaupun jarang terjadi, beberapa kali pelaksanaan hari raya Nyepi bersamaan dengan hari Jum'at. Tak pelak masalah muncul ke permukaan. Terakhir pada tahun 2008, hari raya Nyepi jatuh pada hari Jum'at. Berdasar surat edaran Gubernur Bali No. 003.2/15.743/Dishub Tahun 2008, Pemerintah Provinsi Bali, dalam hal ini Gubernur Bali mengeluarkan himbauan tentang pelaksanaan Shalat Jum'at. Salah satu isi himbauan adalah kebolehan umat Islam melaksanakan sholat Jum'at di Masjid dengan beberapa syarat antara lain; tidak boleh menggunakan kendaraan bermotor untuk pergi ke masjid, pengeras suara luar tidak diperbolehkan.

Wujud teknis penyelengaraan aturan ini telah disosialisasikan dan dipraktekkan sedemikian rupa. Artinya tidak menjadi persoalan serius bagi pengurus takmir musholla/masjid. Justru persoalannya adalah banyak umat Islam yang tidak mungkin dapat melaksanakan sholat Jum'at karena berdomisili jauh dari musholla/masjid.

Padahal Shalat Jum'at adalah salah satu kewajiban yang sangat difardlukan bagi umat Islam. Sebagaimana termaktub dalam al-Qur'an surat al-Jumu'ah (62) ayat 9:

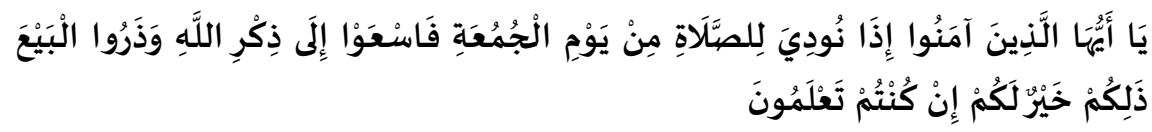

Artinya: Hai orang-orang beriman, apabila diseru untuk menunaikan shalat Jum'at, Maka bersegeralah kamu kepada mengingat Allah dan 
tinggalkanlah jual beli. yang demikian itu lebih baik bagimu jika kamu mengetahui."

Dalam beberapa hadisnya, Rasulullah Saw. juga menekankan betapa pentingnya shalat jum'at, diantaranya:

"Barangsiapa meninggalkan shalat jum'at tiga kali, karena menganggap enteng maka Allah akan menutup mata hatinya." (HR. Aḥmad, Abu Dāwud dan Hakim)

"Barangsiapa yang meninggalkan shalat jum'at tiga kali, tanpa alasan, maka Allah mencatatnya termasuk golongan orang-orang yang munafik." (HR. Țabrāni)

"Hendaklah orang itu menghentikan perbuatan mereka meninggalkan shalat Jum'at atau jika tidak, Allah akan menutup mata hatinya. Kemudian mereka akan termasuk orang-orang yang alpa." (HR. Muslim).

Fakta sosial yang terjadi, beberapa kelompok masyarakat Muslim di Bali menggunakan cara pandang fiqh yang berbeda dalam menyikapi hal ini. Salah satu di antaranya ada yang merujuk pada pendapat golongan Syafiiah tentang penggunaan satu masjid dalam satu kewilayahan desa. Hal ini didasarkan hadis yang diriwayatkan oleh Aisyah:

Diriwayatkan dari Aisyah istri Nabi Saw. Ia berkata: "Pada hari Jum'at orang-orang berduyun pergi ke masjid dari rumah mereka dan al-'Awali (yaitu tempat yang ada di Timur kota Madinah jaraknya sekitar 4 mil)."19

Hadis inilah yang dijadikan dasar Imām Shafi'ì di dalam al'Umm tentang tidak bolehnya mendirikan shalat Jum'at lebih dari satu di satu kewilayahan desa. ${ }^{20}$ Paham shafi'i ini otomatis tidak dipakai oleh Muslim Bali saat Nyepi, jangankan solat jamaah Jum'at melebihi dua kelompok, bisa ada tempat untuk solat Jum'at saja sudah bersyukur karena tidak semua wilayah ada masjidnya. Kadang dalam satu kecamatan hanya ada satu masjid penyelenggara shalat Jum'at.

Ini menjadi persoalan besar karena saat Nyepi, kesulitan untuk keluar rumah sangat tinggi, kalau pun sakit sehingga harus

${ }^{19}$ Hadis No. 851, Abi Abd al-Lah Muhammad bin Ismā'il al-Bukhārī, Șaḥih Bukhari (Bayrūt: Dār al-Fikr, tt.)

${ }^{20} \mathrm{Abi}$ Abd al-Lah Muḥammad bin Idris al-Ṣafi'̄í al-'Umm (Bayrūt: Dār al-Fikr, tt, Juz I), 192. 
ke rumah sakit maka harus diantar pecalang (petugas keamanan dari desa adat), maka bila Muslimin yang berumah jauh dari masjid memilih hendak shalat Jum'at, di setiap desa adat yang dilewati dia harus minta izin dan bahkan di beberapa tempat harus diantar petugas keamanan. Pernah terjadi, seorang Muslimin yang hendak shalat jum'at harus diantar tiga petugas keamanan karena dari rumahnya ke masjid terdekat harus melewati tiga desa adat.

Sementara itu Imam Ramli, salah seorang pentaskbikh golongan Syafi'iyyah memiliki pendapat lain. Imam Ramli berpendapat bahwa pendirian satu shalat Jum'at di satu kewilayahan desa bisa ditiadakan apabila ada kemashlahatan yang menuntutnya, seperti sulitnya untuk berkumpul karena masjid yang terlalu kecil dan atau jumlah masjid yang sangat terbatas, berjauhan ataupun karena ada perselisihan yang sulit disatukan. ${ }^{21}$

Meski fakta sosialnya berbeda namun pelaksanaannya sama, yakni tidak shalat Jum'at. Di hari, di mana umat Islam memiliki kewajiban yang utama untuk beribadah, di sisi lain lingkungan dan situasi tidak mendukung. Dari beberapa laporan yang masuk melalui Majelis Ulama Indonesia maupun yang sudah diekspos oleh media elektronik di Bali, tampak jelas, bahwa praktek yang terjadi di pulau Dewata sangat beragam. Ada kelompok masyarakat Muslim yang rata-rata berjumlah tidak lebih dari 10 (sepuluh) orang, terpaksa melaksanakan shalat Jum'at dikarenakan letak masjid/mushala sangat jauh. Ketika ditanyakan tentang alasan secara fiqh/hukum, sebagian besar hanya menjawab secara sederhana, yang penting bisa melaksanakan shalat Jum'at.

Ditinjau dari segi penamaannya, memang shalat Jum'at itu dilaksanakan secara berjamaah. Tentang bilangan shalat Jum'at, para fuqaha berbeda pendapat, di antaranya:

a. Golongan Hanafiyyah berpendapat bahwa shalat Jum'at sah dilakukan oleh empat orang, salah seorang dari mereka menjadi imam. Ada juga yang berpendapat sah dilakukan oleh tiga orang.

${ }^{21}$ Muhammad Shams al-Dīn al-Ramli, Nihayah al-Mubtaz. (Bayrūt: Dar al-Fikr, tt, Juz II), 289. 
b. Golongan Syafi'iyyah dan Hanabilah berpendapat harus terdiri dari jumlah yang mencukupi, paling sedikit 40 orang.

c. Golongan Malikiyyah berpendapat tidak disyaratkan jumlah tertentu. Melainkan disyaratkan adanya sekelompok orang yang dengan mereka terbentuklah satu perkampungan dan terjadi jual beli di antara mereka. Hal ini tidak akan terjadi hanya dengan adanya tiga atau empat orang atau jumlah yang sepadan dengan itu.

Menyikapi aturan tersebut, Muslimin di Bali, terutama saat pelaksaan Nyepi, umumnya lebih dekat dengan golongan pertama. Terutama bagi Muslim yang bermukim jauh dari pusat kota dan pantai yang umumnya lebih banyak umat Islam yang berdiam di dua kawasan tersebut dibandingkan mereka yang tinggal di pelosok dan pegunungan.

\section{Memadamkan Api dalam Sekam}

Interaksi sosial antara umat Islam dan Hindu di Bali memiliki latar belakang sejarah yang cukup panjang. Meski hubungan antara umat Islam dan Hindu di Bali nampak sangat mesra, namun tidak jarang melahirkan perbedaan bahkan pertentangan yang melahirkan konflik agama. Hubungan akrab antara dua umat beragama ini terjadi meski secara kasat mata saja, akan mudah ditemukan perbedaan prinsip antara penganut Hindu dan Islam, terutama dalam hal tata cara peribadatan dan pranata syariah atau aturan keagamaan lainnya.

Hal ini menunjukkan bahwa kehidupan beragama di Bali tercermin dengan diakuinya eksistensi agama Islam, Kristen, Protestan, Katolik, Hindu, dan Budha, sebagaimana yang tercermin dalam Keputusan Menteri Agama Nomor 35 Tahun 1980 tentang Wadah Musyawarah Antar Umat Beragama. Meskipun, dalam kenyataan terdapat agama lainnya, seperti Konghucu dengan majlisnya yang bernama Matatakin. Kelima agama dan yang lainnya itu merupakan potensi dan kekayaan utama bagi pembinaan mental dan spiritual bangsa. Sebab, tiap agama dalam ajarannya mewajibkan umatnya untuk mencintai sesamaanya dan hidup rukun.

Usaha untuk memberi "titik temu" agama-agama, kiranya perlu dibingkai dalam format ketuhanan yang Maha Esa. Semua 
itu berasal dari satu Tuhan, maka pada tingkat transenden, kata Frithjof Schoun, semua agama akan mencapai titik temu. Atau, bagi Huston Smith (1973) bahwa landasan esoterik agama-agama itu sama. Sementara dalam perspektif filsafat parennial, kesamaan itu diistilahkan dengan transcendent unity of religions (kesamaan transenden agama-agama). Jadi, pada tingkat the common vision (Huston Smith) atau pada tingkat transcendent (kaum parennialis) semua agama mempunyai kesatuan. Kalau tidak, malah kesamaan gagasan dasar.

Dalam konteks pluralitas agama, penerimaan adanya the common vision ini berarti menghubungkan kembali the many dalam hl ini realitas eksoteris agama-agama, kepada asalnya The One, Tuhan, yang diberi berbagai macam nama oleh para pemeluk berbagai agama sejalan dengan perkembangan kebudayaan dan kesadaran sosial dan spiritual manusia. Sehingga, kesan empiris tentang adanya agama-agama yang plural itu tidak hanya berhenti sebagai fenomena faktual saja. Akan tetapi, kemudian dilanjutkan bahwa ada satu realitas yang menjadi pengikat yang sama dari agama-agama tersebut, yang dalam bahasa simbolis bolehlah kita sebut dengan "agama itu". 22

Agama yang satu berbeda dengan agama yang lain, tetapi kebenaran lain pun tak boleh disangkal bahwa di antara agamaagama itu terdapat persamaan yang seringkali menakjubkan. Kita sering begitu tercengkeram dalam bentuk-bentuk lahir keagamaan yang kita pertahankan mati-matian seolah-olah merupakan benteng terakhir. Padahal, itu sebenarnya merupakan juga produk salah satu generasi pendahulu kita. ${ }^{23}$ Dengan menyadari bahwa pluralitas agama pada akhirnya akan mengantar kepada titik temu agama, asal tidak terpaku pada bentuk lahiriah agama yang eksoteris, namun memandangnya sebagai yang esoteris, sehingga mampu menyadari tentang segisegi agama yang sifatnya relatif, namun mengandung yang absolut. Maka, di situlah akan terdapat dinamika kehidupan beragama, yang berpuncak kepada kerukunan hidup beragama.

\footnotetext{
${ }^{22}$ Sukidi, "Dari Pluraisme Agama Menuju Konvergensi Agama-agama" dalam Kompas, 17 Oktober 1998.

${ }^{23}$ Asfons Suhardi, Kompas, 25 Oktober 1986
} 
Kehidupan beragama yang dinamis merupakan faktor dasar yang bersifat menentukan bagi terwujudnya stabilitas nasional, persatuan dan kerukunan, perdamaian dan ketenangan hidup, kehidupan beragama yang dinamis dengan terciptanya kerukunan umat beragama tentu saja membawa manfaat yang sangat besar. Untuk umat beragama terwujudnya kerukunan umat beragama mempunyai manfaat, minimal terjaminnya serta dihormatinya iman dan identitas mereka oleh pihak lain, dan maksimal adalah terbukanya peluang untuk membuktikan keagungan agama mereka masing-masing dalam hidup bermasyarakat, berbangsa, dan bernegara. ${ }^{24}$

\section{Catatan Akhir}

Hubungan antar umat beragama di Bali, terutama antara Hindu dengan Muslim, sebagaimana bukti sejarah, telah berlangsung dalam waktu yang cukup lama. Hal ini, minimal, telah memberi waktu yang cukup untuk saling memahami dan menghargai peribadatan masing-masing pemeluk agama. Dengan melihat kondisi obyektif yang terjadi, rasa penghormatan yang terjalin selama ini akan terus berkembang berdasarkan rasa keadilan terutama dalam hal pelaksanaan ibadah masing-masing pemeluk agama.

Hanya saja, ada prasyarat yang harus dipatuhi, terutama dari kalangan Muslim yang hanya berjumlah sekira 5,2 persen dari total penduduk dengan jumlah 9 kabupaten dan kotamadya itu. Di antaranya, Muslim senantiasa mampu berijtihad, berpikir dan bertindak toleran terhadap budaya tuan rumah tanpa mengorbankan akidah Islam yang dianutnya.

Seiring perkembangan zaman, hal ini menuntut inovasi dan renovasi terhadap ejawantah dari nilai-nilai lokal dan menyeiringkannya dengan nilai Islam tanpa menyinggung perasaan penduduk setempat. Misalnya dalam hal makanan, Muslim harus tegas dengan tidak mengkonsumsi menu yang mengandung unsur babi. Namun demikian kala hadir di sebuah

\footnotetext{
${ }^{24}$ Moerdiono, "Makna Kerukunan Hidup Umat Beragama Menurut Tinjauan Paham Negara Kesatuan Republik Indonesia: Beberapa Pokok Pikiran”, Makalah yang tidak diterbitkan, Jakarta, Sarasehan Sehari Majlis Ulama Indonesia, 5 Nopember 1966.
} 
undangan, dituntut untuk menghormati pengundangnya dengan memakan hidangan yang paling "jauh" dari unsur yang diharamkan tersebut. Sebagaimana terjadi saat ini, maka umat Hindu akan menyesuaikan diri dengan menyediakan menu halal kepada tamu Muslimnya. Wa al-Läh a lam bi al-sawāb.

\section{Daftar Pustaka}

Abdullah, Irwan. 2009. Konsturksi dan Reproduksi Kebudayaan. Yogyakarta: Pustaka Pelajar.

al-Bukhārī, Abi 'Abd al-Lāh Muḥammad bin Ismācil. tt. Saḥih Bukhārì. Bayrūt: Dār al-Fikr.

Cassanova, Jose. 2011. Agama di Ruang Publik: Kehidupan Dunia di Alam Modern. Malang: Resist Book.

Huntington, Samuel P. 1993. "Benturan Antar Peradaban, Masa Depan Politik Dunia?” dalam Jurnal Ulumul Qur'an, No. 5, Vol. IV.

Koentjaraningrat. 1978. Kebudyaaan, Mentalitet dan Pembangunan. Jakarta: Gramedia.

Masykur. tt. "Pola Komunikasi Antar Umat Beragama: Studi atas Dialog Umat Islam dan Kristen di Kota Cilegon Banten" Article Annual conference on contemporary Islamic studies. Jakarta.

Moerdiono. "Makna Kerukunan Hidup Umat Beragama Menurut Tinjauan Paham Negara Kesatuan Republik Indonesia: Beberapa Pokok Pikiran", Makalah yang tidak diterbitkan, Jakarta, Sarasehan Sehari Majlis Ulama Indonesia, 5 Nopember 1966.

Mudzhar, M. Atho. 2005. "Pengembangan Masyarakat Multikultural Indonesia dan Tantangan ke Depan: Tinjauan dari Aspek Keagamaan", dalam M. Ridwan Lubis (ed.), Meretas Wawasan dan Praksis Kerukunan Umat Beragama di Indonesia. Jakarta: Badan Litbang Agama dan Diklat Keagamaan Puslitbang Departemen Agama.

Parimastha, I Gde. 2005. "Memahami Ddesa Adat, Desa Dinas dan Desa Pekraman (Suatu Tinjauan Historis Kritis)", Makalah. Bali: Universitas Udayana Bali. 
Pemda Tk. I Bali. 1997/1998. Sejarah Masuknya Agama Islam ke Bali. Bali, Proyek Peningkatan Sarana dan Prasarana Kehidupan Beragama.

Pidada, Utami. 1999. "Ahimsa, Gaya Hidup Tanpa Kekerasan", dalam Helmy Faisal Zein, et.al (ed.), Agama dan Kekerasan, dari Anarkisme Politik ke Teologi Kekerasan. Jakarta: Elsas.

al-Ramli, Muḥammad Shams al-Dīn. tt. Nihāyah al-Mubtaz: Bayrūt: Dār al-Fikr, Juz II.

Suhardi, Asfons. Kompas, 25 Oktober 1986.

Sukidi. "Dari Pluraisme Agama Menuju Konvergensi Agamaagama" dalam Kompas, 17 Oktober 1998.

Suryadinata, Leo. et.al. 2003. Indonesia's Population. Singapore: Institue of Southeast Asian Studies (ISEAS).

Susetyo, Romo Beny. 2005. "Agama dan Konflik Sosial: Merajut Persaudaraan Sejai", dalam H.M. Ridwan Lubis (ed.), Meretas Wawasan dan Praksis Kerukunan Umat Beragama di Indonesia. Jakarta: Badan Litbang Agama dan Diklat Keagamaan Puslitbang Departemen Agama.

al-Shafi' 1', Abi 'Abd al-Lāh Muhammad bin Idris. tt. al-'Umm. Bayrūt: Dār al-Fikr, Juz I. 